infected with HIV helping and supporting each other, offering each other love and compassion, determined to challenge and contradict the notions that HIV was "deserved," a moral contamination, and that people with HIV were "finished."

The second thing that saved my self esteem was anger. Anger at a medical system which allows doctors to do a professional job by reaching a diagnosis, but which equips them with neither the insight to recognise that in giving that diagnosis they may be taking away so much that gives meaning and purpose to life, nor the skill to help their patients find a way to replace that loss. Anger, too, at finding out that doctors and health care workers were as vulnerable as anyone else to irrational fears and could even allow prejudice to undermine their special commitment to caring for the sick.

I was angry mostly at discovering that it could be tantamount to a crime to have a disease. I have been very fortunate. I have not lost a job, my income, my flat, my friends, or the love of my family because I have "the AIDS virus." Others have. It is why people who have HIV are so afraid of losing control over who knows. For me there are few risks in other people knowing. For me concealment is not a satisfactory strategy for coping with the disease. It should not have to be a strategy for anyone. If you have to conceal things it implies that you are not fully in control of your life. It aggravates that sense of isolation.

Ironically, the quality of my life has improved considerably since the crisis I went through. The reassessment it forced of my values and relationships has brought enormous rewards. I have adapted to my new circumstances. Doctors can make that process of adaptation less painful for their patients by becoming aware of the obstacles that may make it difficult for patients to come to terms, emotionally, socially, and psychologically, with the diagnosis and how patients could and should be helped. For example, it is essential that doctors refer patients to counsellors and agencies able to assess and meet their needs.

It is essential, too, that doctors share with their patients a concept of health where "health" is not defined as longevity. We know that people react to crises somewhere between one extreme of saying, "There is nothing I can do about this; I am the victim of circumstances beyond my control" and the other extreme of saying, "I can be in control of what happens to me, and I can change things for the better through my own actions." Doctors can help patients move towards that determination to achieve a sense of wellbeing through their own actions. In the absence of a cure for HIV, it is possible, with encouragement from one's doctor, to achieve one's own personal and private victories against this disease.

\title{
Medicolegal
}

\section{Consent and the mentally handicapped}

\author{
CLARE DYER
}

Does the court have power to consent to an operation on a mentally handicapped adult who cannot give valid consent? That question was left hanging in the air when the House of Lords delivered judgment in the "Jeanette" sterilisation case last April.' Sunderland Borough Council made Jeanette a ward of court before her 18th birthday so the court could give its consent under the wardship jurisdiction, which applies only to minors.

Once she reached 18, it was thought, no one, not even the court, would have power to consent. But while the case was progressing through the courts some commentators cast doubt on this interpretation of the law. They suggested that the court retained some residual jurisdiction after 18 to take decisions on behalf of those who were mentally incapable of deciding for themselves, under the ancient common law principle of the state as parens patriae.

London NW1

CLARE DYER, BA, BLS, legal correspondent
The point was raised in the House of Lords, but their lordships were unwilling to commit themselves without the benefit of full argument, for which time was too short. For the same reason the power was not argued in two subsequent last minute court applications to sanction abortions on mentally handicapped women. In both these cases the judges did not give consent to the abortion but simply made a declaration that doctors would not be committing an unlawful act in performing the operation.

Now the case of $T,{ }^{2}$ a 19 year old Welsh girl with a mental age of less than 3 , has confirmed that the court has no power to consent to operations under the parens patriae jurisdiction. $T$, with an intelligence quotient of less than 30 , is doubly incontinent, uncooperative, and destructive and is taking large doses of drugs to control epilepsy. Her pregnancy was discovered at only 11 weeks, so there was time for the point to be fully argued. Mr Justice Wood's judgment confirms that the residual jurisdiction may still exist but there is now no one who can exercise it. The Crown's ancient prerogative rights over "mentally disordered persons" were delegated to the Lord Chancellor under the royal warrant. But the last royal warrant was revoked in 1960, when the Mental Health Act 1959 came into force. 


\section{No power of consent}

The Act allowed for the appointment of a guardian who could consent to medical treatment. But in the Act which replaced it, the Mental Health Act 1983, the guardian can consent only to psychiatric treatment. The change was influenced by Mencap's argument that mentally handicapped people should have greater rights of self determination. But it has left a gap in the law whereby nobody can consent to an operation on a severely mentally handicapped adult.

In T's case, where sanction was sought for an abortion and sterilisation, Mr Justice Wood had no alternative but to fall back on the expedient adopted by his brother judges in the two earlier cases. Order 16 rule 15 of the Rules of the Supreme Court allows the court to make a simple declaration about the rights of the parties. It has been used in a wide variety of cases-to declare, for example, a mortgage or a contract invalid, a lottery lawful, a foreign judgment invalid, and, in the "Sikh turban" case, a headmaster guilty of racial discrimination.

The practice is not to give a declaration relating to future events, however, except in very special circumstances. His lordship decided that this was such a case and exercised his discretion to give the declaration. An operation without consent is a trespass to the person and therefore prima facie unlawful, so on what basis could the court declare such an assault to be justified?

His Lordship said he was convinced that it was in the best interests of the girl that the procedures should be performed. He was content to rely on the principle that in exceptional circumstances, where there was no provision in law for consent and no one who could give consent and where the patient was suffering such mental abnormality as to be unable ever to give consent, then a medical adviser was justified in taking such steps as good medical practice demanded. He also called for urgent consideration to be given to a speedy restitution of the prerogative powers invested in the Crown as parens patriae, which would give the court power to consent to operations.

\section{A court declaration in every case?}

Where do doctors stand now? Do they need to seek the protection of a court declaration in every case, or can they rely on their own judgment of what "good medical practice" demands? After all, doctors have been carrying out abortions, sterilisations, and other operations on mentally handicapped people for years, without apparently incurring professional proceedings or actions for assault. On the other hand, Lord Templeman has clearly warned in the
House of Lords: "Sterilisation of a girl under 18 should only be carried out with the leave of a High Court judge. A doctor performing a sterilisation operation with the consent of the parents might still be liable in criminal, civil, or professional proceedings. A court exercising the wardship jurisdiction emanating from the Crown is the only authority which is empowered to authorise such a drastic step as sterilisation after a full and informed investigation."

As Mr Justice Wood put it: "In the absence of clarity of the law, the medical profession wishes to come to the High Court for $\mathbb{D}$ orders." In the case of sterilisation doctors would be unwise to proceed without making the girl a ward of court if she is under 18 or $\varrho$ seeking a declaration if she is over. The cautious line would be to do so for abortions as well, but the problem of lack of consent applies $\stackrel{5}{\hookrightarrow}$ equally to other operations and medical treatments not just to those relating to the reproductive function.

The Medical Defence Union and the Medical Protection Society each receive about one inquiry a month on this subject. The MDU $\mathbb{\mathbb { Q }}$ advises that doctors should not perform an abortion or sterilisation on a severely mentally handicapped woman or girl without consent or sanction from the court, but that it is not for the doctor to seek. consent. "We take the view that if a member of ours sees clinical reasons for treatment he should offer the treatment but he shouldn't $\stackrel{\circ}{\circ}$ try to engineer the acceptance," said the deputy secretary Dr John 욱 Wall. "That is usually for the next of kin or the health authority."

Dr Roy Palmer of the Medical Protection Society said: "On of abortion, the MPS advises that the law is uncertain, and until it is clarified doctors who wish to treat mentally impaired patients of should seek advice in the light of the facts of the specific case. Whilst $N$ uncertainty in the law persists there are, broadly, two approaches. ज One is the legally defensivist approach of playing safe, but the $\mathrm{O}$ disadvantage is that the patient may suffer. The alternative and, arguably, better view is to exercise good clinical judgment and to do of what is in the best interests of the patient. The MPS will be pleased $ᄃ$ to offer advice and support to doctors who act in the best interests of their patients.

"On sterilisation, as the law stands, there appears to be real doubt $\stackrel{\infty}{v}$ as to whether sterilisation of the mentally handicapped on social $\square$ grounds is lawful under English law. The MPS would therefore advise members not to perform sterilising operations on minors or on mentally impaired adult patients until satisfied that such a procedure is lawful."

\section{References}

1 Dyer C. Sterilisation of mentally handicapped girl authorised. BrMed $\mathcal{J}$ 1987;294:1219-20. 2 In re T; $\mathrm{T} v \mathrm{~T}$ and another. The Times 1987; July 11.

\section{DOCTORS IN SCIENCE AND SOCIETY}

\section{William Hillary}

Nothing is known of Hillary's day to day work during his early years in Bridgetown. But one visitor to Barbados has left an account of a professional visit from Dr Hillary in 1751. The writer was a young Virginian, aged 19, who had brought his elder brother to Barbados for his health. The elder brother had developed ominous signs of consumption and had been ordered to spend the winter in a warmer climate than Virginia. They arrived in Bridgetown on 3 November, where they met Major Gedney Clarke, who was Collector of His Majesty's Customs and a member of the island's council. The writer recorded in his diary for 5 November 1751:

Early this morning came Dr. Hilary, an eminent physician recommended by Major Clarke, to pass his opinion on my brother's disorder, which he did in a favourable light, giving great assurance, that it was not so fixed but that a cure might be effectually made. In the cool of the evening we rode out accompanied by $\mathrm{Mr}$. Carter to seek lodgings in the country, as the Doctor advised, and were perfectly enraptured with the beautiful prospects, which every side presented to our view-the fields of cane, corn, fruit trees, all in a delightful green.
The patient referred to in this passage was none other than Lawrence Washington, of Mount Vernon in Virginia, who had a connection by marriage with Gedney Clarke. The young diarist was his stepbrother, George Washington, inheritor of Mount Vernon, commander of the armies of the American colonies in the War of Independence, first president of the $\mathrm{N}$ United States of America. Dr Hillary's favourable prognosis is at first 0 difficult to reconcile with his patient's subsequent progress. Lawrence spent 0 three months in Barbados, then went to Bermuda. He arrived home in Virginia in the following June, a shadow of his former self, and died on $24 \stackrel{Ð}{\rightleftharpoons}$ July 1752. But the modern physician would approve Hillary's cheerful approach. He must have been familiar with pulmonary tuberculosis, must have himself known what the prognosis might be. Yet no physician will $\overrightarrow{\mathbb{D}}$ readily leave his patient without hope, whose therapeutic effects are mysteriously effective, and there is therefore much to commend in Hillary's encouragement.-CHRISTOPHER BOOTH.

Doctors in Science and Society by Christopher Booth. Published under the BMF's Memoir Club imprint on 30 June 1987. ISBN 072790189 3. Price $£ 14.95$; overseas $£ 19.50$; USA $\$ 32$. BMA members $£ 13.95$; overseas $£ 18.50$; USA $\$ 30$. 